\title{
O DIREITO AO PLANEJAMENTO FAMILIAR E AS NOVAS FORMAS DE PARENTALIDADE NA LEGALIDADE CONSTITUCIONAL
}

\author{
Vitor Almeida*
}

\begin{abstract}
Sumário: Notas introdutórias: família e parentalidade na contemporaneidade 1. O direito ao planejamento familiar entre a liberdade e a solidariedade -2 . Os limites do direito ao planejamento familiar na legalidade constitucional - 3. A família contemporânea e as novas formas de parentalidade: 3.1. A monoparentalidade planejada através da reprodução assistida; 3.2. O reconhecimento jurídico da multiparentalidade planejada - Considerações finais - Referências.
\end{abstract}

\section{NOTAS INTRODUTÓRIAS: FAMÍLIA E PARENTALIDADE NA CONTEMPORANEIDADE}

$\mathrm{Na}$ contemporaneidade é crescente o fenômeno consistente no aparecimento de arranjos familiares que não se fundam no modelo tradicional de família biológica, de configuração heterossexual, monogâmica, hierárquica e nuclear. Com isso, novas formas de se exercer e vivenciar a parentalidade são constatadas no meio social e merecem tutela jurídica, distanciando da tradicional estrutura fundada na biparentalidade heterossexual, surgindo, dentre outras formas possíveis, por exemplo, a monoparentalidade por opção, a multiparentalidade e a homoparentalidade. Os agrupamentos familiares sempre se modificaram diante da dinamicidade inerente

* Doutor e mestre em Direito Civil na Universidade do Estado do Rio de Janeiro (UERJ). Professor de Direito Civil do Departamento de Direito, Humanidades e Letras do ITR-UFRRJ. Professor de Direito Civil da PUC-Rio. Professor convidado dos Cursos de Especialização em direito civil-constitucional do CEPED-UERJ e em direito do consumidor e responsabilidade civil da EMERJ. Advogado. 
ao fenômeno familiar, mas o que se mostra peculiar nesse momento histórico são a intensidade e a velocidade com que essas mudanças acontecem. ${ }^{1}$

Ainda que, socialmente, a parentalidade continue associada à conjugalidade, em termos jurídicos, a Constituição da República de 1988 coroou a desvinculação entre a filiação e o casamento, ou seja, o estado de filho adquiriu independência frente à situação conjugal dos genitores ${ }^{2}$, a partir do reconhecimento da plena igualdade entre os filhos ${ }^{3}$ e da superação da discriminatória e odiosa díade entre prole legítima e ilegítima. O estabelecimento do vínculo paterno-filial independe da constância de justas núpcias entre seus genitores, ou seja, o projeto reprodutivo não mais se vincula ao matrimônio.

A família contemporânea, portanto, desvinculou-se da exclusividade do vínculo matrimonial como forma legítima de constituição familiar, notadamente com a promulgação da Constituição da República de 1988, que, finalmente, recepcionou as alterações da realidade social e a evolução jurisprudencial, estabelecendo novas diretrizes jurídicas, a exemplo da dignidade da pessoa humana e solidariedade familiar. Modificou-se a vocação da familiaridade, que passa a abarcar uma pluralidade de entidades familiares, e, a partir de sua concepção instrumental, afigura-se como o grupo social intermédio hábil a proporcionar o desenvolvimento dos membros da comunidade familiar. A par destas mudanças, agregam-se os efeitos da biotecnociência, particularmente o fenômeno da reprodução assistida, que possibilitou a constituição de famílias monoparentais multiparentais de forma planejada, viabilizando, assim, que o projeto reprodutivo seja uma decisão deliberada de eventual genitor solteiro ou de três ou mais pessoas em situação de conjugalidade ou não.

A família vivencia atualmente um processo de democratização que compreende a busca pelo ideal da igualdade e da liberdade ${ }^{4}$ em seu interior e a adoção de valores e práticas democráticos ${ }^{5}$, com a diminuição do discurso autoritário e a

1 LIPOVETSKY, Gilles. A Sociedade Pós-Moralista: o crepúsculo do dever e a ética indolor dos novos tempos democráticos. Trad. de Armando Braio Ara. Barueri: Manole, 2005, p. xxxiiii.

2 BARBOZA, Heloisa Helena. Novas relações de família e paternidade. In: Anais do Congresso Brasileiro de Direito de Família, Belo Horizonte: Del Rey, 1999, p. 136.

3 "Art. 227, $\$ 6^{\circ}$ Os filhos, havidos ou não da relação do casamento, ou por adoção, terão os mesmos direitos e qualificações, proIbidas quaisquer designações discriminatórias relativas à filiação.

4 Cf. MULTEDO, Renata Vilela. Liberdade e família: limites para a intervenção do Estado nas relações conjugais e parentais. Rio de Janeiro: Processo, 2017.

5 Para Anthony Giddens, "a família está se tornando democratizada, conforme modos que acompanham processos de democracia pública; e tal democratização sugere que a vida familiar poderia combinar escolha individual e solidariedade social" ( $A$ Terceira Via: reflexôes sobre o impasse político atual e o futuro da social-democracia. Rio de Janeiro: Record, 2000, p. 98). 
valorização da afetividade ${ }^{6}$. Alvejada tanto por mutações constantes no substrato social, mas aceleradas no fim do século passado pelo desenvolvimento da biotecnociência, quanto no substrato axiológico, agora de índole constitucional, o contexto social e jurídico no qual se insere a familiaridade hodierna, além das importantes modificações já operadas, tem desempenhado um papel crucial na valorização e promoção da dignidade e pleno desenvolvimento da pessoa humana, a qual diante do atual ordenamento pátrio afigura-se como valor central de todo o sistema, que tem na Constituição sua orientação e seu fundamento, direcionando todo seu arsenal à integral proteção do ser.

Assim, da matrimonialização à pluralização da família, houve o reconhecimento, na Constituição da República de 1988, de novas entidades familiares, que objetivam o desenvolvimento da pessoa humana, compreendendo-as como um espaço democrático ${ }^{7}$, no qual deve imperar a confiança e afeto recíprocos. Assim, em função das opções e valores constitucionais inseridos a partir de 1988, alterou-se, de uma vez por todas, a concepção de família no ordenamento brasileiro, que passa a albergar em seu conceito a flexibilidade, quanto às diversas formas de estruturas familiares $^{8}$, e a instrumentalidade, voltando-se para a realização e desenvolvimento da personalidade de seus membros. Concebe-se, desse modo, a família-instrumento ou a família-serviente que é exatamente a sua vocação como grupo intermediário hábil a proporcionar um ambiente favorável às necessidades existenciais de cada um e de todos, com base no relacionamento respeitoso, cooperativo e solidário. ${ }^{9}$

Se antes atrelada a valores matrimoniais e patrimoniais, o desejo de ter um filho constituía uma das finalidades do casamento, como "consequência natural da satisfação do 'débito conjugal'"10, agora, desvinculada das exigências de uma união

6 Sobre o assunto, cf. CALDERON, Ricardo Lucas. Princípio da Afetividade no Direito de Família. Rio de Janeiro: Renovar, 2013.

7 Sobre a construção de um novo modelo familiar democrático e suas características jurídicas no cenário nacional remete-se a BODIN DE MORAES, Maria Celina. A família democrática. In: Na medida da pessoa humana: estudos de direito civil-constitucional. Rio de Janeiro: Renovar, 2010, p. 207-234.

8 Para uma análise da pluralidade de entidades familiares no ordenamento brasileiro sugere-se a leitura de MATOS, Ana Carla Hermatiuk. "Novas" entidades familiares. In: (Org.). A construção dos novos direitos. Porto Alegre: Núria Fabris, 2008, p. 16-32.

9 BODIN DE MORAES, Maria Celina. A família democrática. In: Na medida da pessoa humana: estudos de direito civil-constitucional. Rio de Janeiro: Renovar, 2010, p. 216.

10 BARBOZA, Heloisa Helena. Direito à procriação e às técnicas de reprodução assistida. In: Eduardo de Oliveira Leite et all. Grandes temas da atualidade: bioética e biodireito. Rio de Janeiro: Forense, 2004, p. 157. 
formal, passa a ser concebida como um projeto de vida, intimamente relacionado à autonomia reprodutiva e ao próprio desenvolvimento da personalidade de quem almeja ser genitor. Nada obstante, as possibilidades de concretização do desejo parental aumentaram potencialmente com o recurso às técnicas de reprodução assistida, as quais trouxeram novos problemas à familiaridade contemporânea. Assim, as novas formas de parentalidade, como a monoparentalidade por opção e a multiparentalidade planejada, desafiam o modelo biparental e a estrutura normativa forjada.

Tais arranjos familiares se tornaram possíveis graças às técnicas de reprodução humana assistida, que, em princípio, eram destinadas a casais heterossexuais inférteis. Não tardou, no entanto, que grupos sociais não contemplados inicialmente pelo discurso biomédico se aproveitassem dessas técnicas como meio de constituir uma família, a exemplo das pessoas solteiras e dos casais homossexuais. A rigor, pouco se debatia sobre as formas de constituição familiar que essas técnicas proporcionavam às pessoas, em conjugalidade ou individualmente, heterossexuais ou homossexuais, e que o nascimento desse novo ser acarretaria na formação de uma nova família, monoparental ou multiparental.

Assim, trata este artigo de analisar o conteúdo e a extensão do direito ao planejamento familiar no direito brasileiro, investigando os limites legais às novas formas de constituição familiar através de projetos parentais unilaterais ou plurilaterais.

\section{O DIREITO AO PLANEJAMENTO FAMILIAR ENTRE A LIBERDADE E A SOLIDARIEDADE}

A Constituição da República de 1988 estabeleceu em seu art. 226, $\$ 7$, o direito ao planejamento familiar como "livre decisão do casal". O texto determina que o Estado disponibilize para o exercício desse direito os recursos educacionais e científicos cabíveis, além de vedar qualquer forma de coerção por parte de instituições oficiais ou privadas que interfira no livre planejamento familiar.

Em que pese o meritório esforço dos constituintes em contemplar o direito ao planejamento familiar em sede constitucional, sua inclusão em artigo disposto no capítulo "Da família, da criança, do adolescente, do jovem e do Idoso" demonstra o apego demasiado de regular os temas relativos à reprodução e à sexualidade dentro do ambiente familiar. Muito mais razoável e democrático seria tutelá-los na esfera do direito à saúde, o que impediria as posições tradicionais que vinculam tal direito às exigências de união entre as pessoas - casamento ou união estável. Sua localização topográfica na Constituição de 1988 não obsta um entendimento do planejamento familiar livre das amarras da tradicional família aristocrático- 
-burguesa, ${ }^{11}$ visto o reconhecimento de entidades familiares outras que não as fundadas no casamento, como as uniōes estáveis e a família monoparental, e a tendência à sedimentação do caráter meramente exemplificativo do rol do art. 226 da Constituição de 1988 , não encerrando qualquer espécie de numerus clausus. ${ }^{12}$

$\mathrm{O}$ art. 226, $\$ 7^{\circ}$, da Constituição de 1988 foi regulamentado através da Lei n. 9.263, de 12 de janeiro de 1996, que trouxe um grande avanço ao dispor que o planejamento familiar é um direito de todo cidadão, não mais contemplando como destinatário unicamente às pessoas casadas ou em união estável. Com a promulgação da lei, dissiparam-se as possíveis dúvidas em relação ao exercício individual de homens e mulheres ao planejamento familiar, entendimento muito mais consentâneo com os princípios constitucionais.

O Código Civil de 2002 introduziu, de maneira acrítica, um dispositivo específico relativo ao planejamento familiar no $₫ 2^{\circ}$, do art. $1.565 .{ }^{13} \mathrm{Na}$ intenção de harmonizar o anacrônico projeto do Código Civil de 1975 com a Constituição promulgada em 1988, o Código Civil acabou por corroborar com a ligação do direito ao planejamento familiar com a família fundada no casamento. Primeiramente, isso se deu por manter o termo "casal" já modificado na lei do planejamento familiar, em consonância com os tratados internacionais e uma interpretação sistemática da Constituição, e, segundo, por inseri-lo no capítulo referente à eficácia do casamento. $\mathrm{O}$ direito ao planejamento familiar, como afirmado, além de não ser restrito às pessoas casadas, em nada comunga com a produção de efeitos do casamento.

Os contornos atuais do direito ao planejamento familiar decorrem, em larga medida, do reconhecimento no plano internacional dos chamados direitos reprodutivos e, por conseguinte, da afirmação da autonomia reprodutiva. $\mathrm{O}$ aspecto conceptivo dos direitos reprodutivos, ou seja, o direito a se ter filhos não constava dentre o rol de reivindicações do movimento feminista, ao menos, em um primeiro

11 Sobre a construção de um novo modelo familiar democrático e suas características jurídicas no cenário nacional remete-se a Maria Celina Bodin de Moraes. A família democrática. In: $\mathrm{Na}$ medida da pessoa humana: estudos de direito civil-constitucional. Rio de Janeiro: Renovar, 2010, p. 207-234.

12 Sobre a não taxatividade do rol de entidades familiares na Constituição, remete-se a Luiz Paulo Netto Lôbo. Entidades familiares constitucionalizadas: para além do numerus clausus. In: PEREIRA, Rodrigo da Cunha (coord.). Família e cidadania - Anais do III Congresso Brasileiro de Direito de Família. Belo Horizonte: IBDFAM, 2002, p. 89-107.

13 “Art. 1.565, [...] $\$ 2^{\circ} \mathrm{O}$ planejamento familiar é de livre decisão do casal, competindo ao Estado propiciar recursos educacionais e financeiros para o exercício desse direito, vedado qualquer tipo de coerção por parte de instituições privadas ou públicas." 
momento, o discurso feminista privilegiou, ao menos, num primeiro momento, "a luta pela descriminalização do aborto e o acesso à contracepção", em virtude da opressão e submissão da mulher ao modelo de família chefiado pelo homem e cristalizado no matrimônio. Maria Betânia de Melo Ávila esclarece que "a formalização da ideia em termos de direitos reprodutivos é bastante recente". ${ }^{14}$

Se, primeiro, os métodos contraceptivos fomentaram uma verdadeira revolução na vida reprodutiva das pessoas, na medida em que permitiram o planejamento familiar consciente e responsável, depois, foram as técnicas de reprodução assistida que alteraram profundamente os modelos familiares. Desse modo, o atual entendimento em torno dos direitos reprodutivos, em sentido contraceptivo e conceptivo, deve-se, segundo Maria Betânia de Melo Ávila, à "redefinição do pensamento feminista sobre a liberdade reprodutiva”, posto que "a concepção e o exercício da maternidade eram possibilidades que, do ponto de vista moral, já estavam dadas, inclusive como prerrogativas fundamentais ou essenciais da existência das mulheres". ${ }^{15}$

Flávia Piovesan sustenta que o conceito de direitos reprodutivos "tem sido assim ampliado, no sentido de abarcar todo o campo relacionado com a reprodução e sexualidade humanas, passando a compreender direitos reprodutivos e sexuais, concebidos no âmbito dos direitos humanos"16. Reconhece, nessa linha, que "a emergência dos direitos reprodutivos como direitos humanos é um fenômeno contemporâneo"17, ou, em outras palavras, os direitos sobre a sexualidade e a reprodução "chegaram tardiamente" 18 . Estes direitos foram consolidados somente com a

14 ÁVILA, Maria Betânia de Melo. Modernidade e cidadania reprodutiva. In: ÁVILA, Maria Betânia de Melo; BERQUÓ, Elza. Direitos reprodutivos: uma questão de cidadania. Brasília: Centro Feminista de Estudos e Assessoria - CFEMEA, 1994, p. 9.

15 ÁVILA, Maria Betânia de Melo. Modernidade e cidadania reprodutiva, cit., p. 9.

16 PIOVESAN, Flávia. Temas de direitos humanos. 2. ed., São Paulo: Max Limonad, 2003, p. 242. Esclarece, ainda, Flavia Piovesan que os direitos reprodutivos correspondem a uma gama diversificada de casos, como o aborto, o adultério, a esterilização cirúrgica, estupro, dentre outros, ressaltando, por isso, que a "abrangência do tema dos direitos reprodutivos dificulta a pesquisa sistemática”. PIOVESAN, Flávia; PIROTTA, Wilson R. Buquetti. Direitos Reprodutivos e o Poder Judiciário no Brasil. In: OLIVEIRA, Maria Coleta; ROCHA, Maria Isabel Baltar da (Org.). Saúde reprodutiva na esfera pública e política na América Latina. Campinas, SP: Unicamp/Nepo, 2001, p. 157.

17 PIOVESAN, Flávia. Temas de direitos humanos, cit., p. 272.

18 Ressalta Cristina Zurutuza que "a primeira menção a que o tamanho da família deva ser 'de livre opção do casal' aparece na Declaração Geral da ONU de 1966“, acompanhada pela Declaração de Teerã de 1968, que incorporou o planejamento familiar como direito. ZURUTUZA, Cristina. Para uma convenção interamericana pelos direitos sexuais e reprodutivos. In: OLIVEIRA, Maria Coleta; ROCHA, Maria Isabel Baltar da (Org.). Saúde reprodutiva na esfera pública e política na América Latina. Campinas, SP; Unicamp/Nepo, 2001, p. 192. 
edição dos instrumentos internacionais de proteção dos direitos humanos nos anos noventa do século passado, em especial pela Declaração e o Programa de Ação sobre População e Desenvolvimento do Cairo de 1994 e pela Declaração e o Programa de Ação de Pequim de 1995. ${ }^{19}$

O Programa de Ação da Conferência Internacional do Cairo sobre População e Desenvolvimento relaciona o conceito de direitos reprodutivos com a definição de saúde reprodutiva, em observância aos preceitos emitidos pela Organização Mundial de Saúde, assegurando que "[...] saúde reprodutiva pressupõe a capacidade de desfrutar de uma vida sexual segura e satisfatória e de reproduzir-se, contando com a liberdade de fazê-lo ou não, quando e com que frequência”. Encontra-se implícito, ainda, "[...] o direito de homens e mulheres à obtenção de informação e a ter acesso a métodos de planejamento familiar de sua escolha que sejam seguros, efetivos, disponíveis e aceitáveis, bem como a outros métodos de regulação da fertilidade de sua escolha não contrários à lei”. ${ }^{20}$

No ordenamento pátrio, embora o termo "direitos reprodutivos" ainda não tenha adquirido assento legal, a Constituição da República de 1988, em seu art. 226, parágrafo $7^{\circ}$, ao dispor sobre o direito ao planejamento familiar, fundado nos princípios da dignidade da pessoa humana e da paternidade responsável, permitiu a introdução, ainda que de modo indireto, da autonomia reprodutiva no sistema jurídico-constitucional brasileiro. Para Heloisa Helena Barboza, o exame do parágrafo 70, do artigo 226, da Constituição Federal de 1988, "permite reconhecer a introdução em nosso sistema de denominada 'autonomia reprodutiva', assegurando-se, para tanto, "o acesso às informações e meios para sua efetivação, ao se atribuir ao Estado o dever de propiciar recursos educacionais e científicos para o exercício desse direito, e ao se vedar qualquer forma coercitiva por parte de instituições oficiais ou privadas". ${ }^{21}$

Segundo Daniel Sarmento, o fundamento da autonomia reprodutiva pode ser extraído da "própria ideia de dignidade humana da mulher (art. 1º, III, CF), bem como nos direitos fundamentais à liberdade e à privacidade (art. $5^{\circ}$, caput e inciso X, CF)", sendo dotada, portanto, "de inequívoco fundamento constitucional"22.

19 PIOVESAN, Flávia. Temas de direitos humanos, cit., p. 272.

20 Programme of action of the UNICPD. Reproductive rights and reproductive health: basis for action, item 7.2, apud, PIOVESAN, Flávia. Temas de direitos humanos, cit., p. 243.

21 BARBOZA, Heloisa Helena. Reprodução humana como direito fundamental, cit., p. 788.

22 SARMENTO, Daniel. Legalização do Aborto e Constituição. In: SARMENTO, Daniel; PIOVESAN, Flávia (Coords.). Nos Limites da Vida: Aborto, Clonagem Humana e Eutanásia sob a Perspectiva dos Direitos Humanos. Rio de Janeiro: Lumen Juris, 2007, p. 43-44. 
Sem embargos, embora não se confundam, o desenvolvimento dos direitos ligados à sexualidade e reprodução humanas preenche e fortalece o conteúdo da autonomia reprodutiva, o que é igualmente verificado com o direito ao planejamento familiar, sobretudo este, por ser o único termo expresso na Constituição da República de 1988, tem sido utilizado como fundamento normativo e axiológico dos outros dois, ainda que de modo reflexo.

A regulamentação infraconstitucional do direito ao planejamento familiar (Lei n. 9.263/1996) não contemplou, contudo, os efeitos do exercício desse direito sobre os arranjos familiares, deixando, por exemplo, a questão da elegibilidade de mulheres e homens solteiros à reprodução assistida e, por consequência, a formação de famílias monoparentais programadas, sem uma solução legal. Também não foi ainda contemplada pelo ordenamento jurídico a possibilidade de multiplicidade de liames parentais de forma planejada entre um casal homoafetivo composto de um dois homens ou duas mulheres e que escolhem um amigo(a) para compartilhar do projeto parental, ou três ou mais pessoas sem nenhum vínculo de conjugalidade ou em situação de poliafetividade.

Essa e outras situações ainda permanecem nebulosas para o direito, principalmente em virtude da morosidade do legislador em regulamentar a proteção dessas novas famílias. Todavia, a inexistência de legislação pertinente não é obstáculo para o debate e muito menos para a possibilidade de aplicação direta da Constituição. $\mathrm{O}$ livre planejamento familiar, assegurado na Constituição, deve ser exercido dentro do contexto de solidariedade imposto pelo desenho constitucional. Segundo Maria Celina Bodin de Moraes, o "princípio da solidariedade [...] é a expressão mais profunda da sociabilidade que caracteriza a pessoa humana". ${ }^{23}$ Dentre os objetivos fundamentais da República brasileira, encontra-se disposto no art. $3^{\circ}$, inciso I, da Constituição de 1988, a construção de uma sociedade livre, justa e solidária. ${ }^{24}$ Daí, afirmar-se que, "no contexto atual, a Lei Maior determina - ou melhor, exige - que nos ajudemos, mutuamente, a conservar a nossa humanidade porque a construção de uma sociedade livre, justa e solidária cabe a todos e a cada um de nós". ${ }^{25}$

Indispensável, portanto, examinar os limites do direito ao planejamento familiar, previsto no art. $226, \$ 7^{\circ}$, no âmbito da legalidade constitucional.

23 BODIN DE MORAES, Maria Celina. O princípio da solidariedade. In: Na medida da pessoa humana: estudos de direito civil-constitucional. Rio de Janeiro: Renovar, 2010, p. 250-251.

24 "Art. $3^{\circ}$ Constituem objetivos fundamentais da República Federativa do Brasil: I - construir uma sociedade livre, justa e solidária."

25 BODIN DE MORAES, Maria Celina. O princípio da solidariedade. In: Na medida da pessoa humana: estudos de direito civil-constitucional. Rio de Janeiro: Renovar, 2010, p. 251. 


\section{OS LIMITES DO DIREITO AO PLANEJAMENTO FAMILIAR NA LEGALIDADE CONSTITUCIONAL}

O próprio dispositivo constitucional estampado no art. $226, \$ 7^{\circ}$, diz que o direito ao planejamento familiar se funda nos princípios da dignidade da pessoa humana e da paternidade (parentalidade) responsável, o que demonstra, expressamente, os seus fundamentos e os parâmetros aceitáveis para seus limites. São esses princípios que devem servir como norte valorativo para a interpretação das limitações ao direito ao planejamento familiar, que, em princípio, deve ser exercido de forma livre e sem interferências alheias. É preciso destacar que o planejamento familiar não é um direito absoluto, mas sujeito a limites que podem se encontrar além dos expressos no dispositivo citado.

O princípio da dignidade humana resguarda tanto os interesses das pessoas que desejam concretizar o desejo parental - na medida em que se considera o direito fundamental a ter família, ${ }^{26}$ a liberdade de viver em família e o entendimento desta como um espaço adequado para o desenvolvimento da personalidade de cada membro -, quanto os do filho a porvir. Afinal, seus interesses têm que ser preservados desde o início da gestação para a promoção de uma vida digna no futuro.

O princípio da parentalidade responsável, ${ }^{27-28}$ ao lado da dignidade da pessoa humana, funda e informa o direito ao planejamento familiar, previsto no art. 226,

26 FACHIN, Luiz Edson. Teoria crítica do direito civil. 2. ed., Rio de Janeiro: Renovar, 2003, p. 37.

27 Em que pese à expressa menção ao termo "paternidade responsável" no art. 226, $\$ 7$ o da Constituição da República de 1988, deve-se conjugar este dispositivo com o art. 229, o qual atribui aos pais o dever de assistir, criar e educar os filhos menores, razão pela qual se prefere denominar de princípio da parentalidade responsável.

28 Guilherme Calmon Nogueira da Gama esclarece que “o termo 'paternidade responsável' não abrange o conteúdo material do limite previsto no $\$ 7^{\circ}$, do artigo 226, da Constituição Federal de 1988, porquanto somente se refere à paternidade, como se a maternidade pudesse ser irresponsável. [...] o exame mais aprofundado do próprio dispositivo, aliado a outras normas constitucionais - por exemplo, a igualdade entre homem e mulher em direitos e deveres -, permite a conclusão de que o constituinte disse menos do que queria, provavelmente por ter sido induzido em equívoco diante da tradução do termo 'parental responsability' que, no entanto, possui outra significação no âmbito do direito inglês”. Assim, sem o cuidado que se deveria ter no transplante jurídico da noção inglesa para o direito brasileiro, o constituinte empregou o termo paternidade responsável quando na realidade o sentido é de parentalidade responsável. De outro lado, é possível encontrar explicação linguística que justifica o emprego do termo 'paternidade responsável' ao considerar que adotou o plural 'pais' para designar ambos os ascendentes - das linhas paterna e materna -, e, por conseguinte, fez-se alusão a paternidade responsável, enquanto referência derivada. De todo modo, é fundamental que se constate que o termo não se limita ao homem, mas logicamente se refere também à mulher que, 
\$ 70, da Constituição da República de 1988. O escopo do exercício da parentalidade responsável, ${ }^{29}$ a partir da livre e consciente decisão sobre a liberdade de pro$\operatorname{criar}^{30}$, se assenta na assunção de deveres em relação ao filho a porvir, seja durante a fase gestacional, em que deve se garantir o sadio desenvolvimento in utero do nascituro e lhe assegurar condiçóes dignas de existência, seja a partir do nascimento com vida da pessoa do filho, em que se efetiva, em concreto, os deveres de assistência, criação e educação dos pais em relações aos filhos menores, conforme disposto no art. 229 da Constituição da República.

Nessa perspectiva, Guilherme Calmon Nogueira da Gama leciona que:

[...] a consciência a respeito da paternidade e maternidade abrange não apenas o aspecto voluntário da decisão - de procriar -, mas especialmente os efeitos posteriores ao nascimento do filho, para o fim de gerar a permanência da responsabilidade parental principalmente nas fases mais importantes de formação e desenvolvimento da personalidade da pessoa humana: a infância e a adolescência, sem prejuízo logicamente das consequências posteriores relativamente aos filhos na fase adulta. ${ }^{31}$

Deve ser afastada a simplista noção de parentalidade responsável como fundamento do estabelecimento do estado de filiação, como se a função desse princípio se destinasse exclusivamente para fins de reconhecimento do vínculo paterno-

desse modo, terá vários deveres decorrentes das consequências e efeitos jurídicos - no campo da filiação - do exercício dos direitos reprodutivos e sexuais" (GAMA, Guilherme Calmon Nogueira. Paternidade responsável e o cuidado: algumas reflexões. In: Andréa Ferreira, Fernando G.; Galvão, Paulo Braga (Org.). Direito contemporâneo: estudos em homenagem a Sergio de Andréa Ferreira. Rio de Janeiro: De Andréa \& Morgado, 2009, p. 326-327).

29 De acordo com Vanessa Ribeiro Corrêa Sampaio Souza, o "princípio da responsabilidade parental, mencionado de forma tímida no art. $226, \$ 7^{\circ}$ da Constituição, expande seu sentido ao ter sua interpretação preenchida pela norma do art. 227 , caput, que coloca a família como um dos entes devedores de respeito aos direitos fundamentais das crianças e adolescentes, e pelo art. 229, que impóe o dever recíproco de cuidado para os pais e filhos, a depender da vulnerabilidade de cada um no decorrer da vida e do desenvolvimento da relação parental" (Sançôes decorrentes da irresponsabilidade parental: para além da destituição do poder familiar e da responsabilidade civil. In: Civilistica.com - Revista Eletrônica de Direito Civil, a. 2, n. 2, 2013, p. 25. Disponível em: <www.civilistica.com>. Acesso 28 jun. 2017).

30 Guilherme Calmon Nogueira da Gama ressalva que "a parentalidade responsável decorre não apenas do fundamento da vontade da pessoa em se tornar pai ou mãe, mas também pode surgir em razão do risco do exercício da liberdade sexual - ou mesmo reprodutiva no sentido mais estrito - no campo da parentalidade" (GAMA, Guilherme Calmon Nogueira. Paternidade responsável e o cuidado: algumas reflexões. In: Andréa Ferreira, Fernando G.; Galvão, Paulo Braga (Org.). Direito contemporâneo: estudos em homenagem a Sergio de Andréa Ferreira. Rio de Janeiro: De Andréa \& Morgado, 2009, p. 328-329).

31 GAMA, Guilherme Calmon Nogueira. Princípio da paternidade responsável. In: Revista de Direito Privado, n. 18, São Paulo: RT, abr./jun., 2004, p. 31. 
-materno-filial, para entender que "[...] a parentalidade responsável representa a assunção de deveres parentais em decorrência dos resultados do exercício dos direitos reprodutivos - mediante conjunção carnal, ou com recurso a alguma técnica reprodutiva". ${ }^{32}$ Qualquer tentativa de diminuição da potencialidade e amplitude do princípio da parentalidade responsável ${ }^{33}$ afronta à unidade da Constituição, que, ainda que o tenha mencionado de forma tímida no art. $226, \$ 7$, estendeu seu âmbito de aplicação e abrangência se examinado conjuntamente com o art. 227 e 229 da Lei Maior.

Vanessa Ribeiro Corrêa Sampaio Souza já afirmou que "o princípio da responsabilidade parental, realizada uma interpretação sistemática, encontra fundamento nos artigos $226, \$ 7 \mathrm{o} ; 227$, caput (que traz a previsão dos direito fundamentais das crianças e adolescentes) e 229 (que institui o dever de cuidado recíproco entre pais e filhos)" ${ }^{34}$ A respeito da abrangência e do alcance do princípio da parentalidade responsável, a autora entende que sua área de incidência "é vasta, alcançando o planejamento familiar, o nascimento e a satisfação das necessidades físicas e psíquicas inerentes ao crescimento humano até que seja alcançada a maioridade, momento em que objetivamente se presume a independência e a maturidade necessárias para justificar o afastamento das atribuições parentais". ${ }^{35}$

32 GAMA, Guilherme Calmon Nogueira. Princípio da paternidade responsável. In: Revista de Direito Privado, n. 18, São Paulo: RT, abr./jun., 2004, p. 30.

33 Ainda que o princípio da paternidade responsável se encontre positivado na ordem constitucional desde 1988, é recente a preocupação da doutrina jurídica, sendo escassos os artigos e textos jurídicos sobre o conteúdo, abrangência e aplicações do referido princípio, salvo honrosas exceçôes. Dentre elas é possível destacar: GAMA, Guilherme Calmon Nogueira da. Princípio da Paternidade Responsável. Revista de Direito Privado, São Paulo, v. 18, abr./jun., 2004, p. 21-41; Paternidade responsável e o cuidado: algumas reflexões. In: FERREIRA, Fernando G. de Andréa; GALVÃO, Paulo Braga (Org.). Direito contemporâneo: Estudos em homenagem a Sergio de Andréa Ferreira. Rio de Janeiro: De Andréa \& Morgado, 2009, p. 317-338; e, Princípio da Paternidade Responsável. In: Ricardo Lobo Torres; Eduardo Takemi Kataoka; Flávio Galdino (Org.). Dicionário de Princípios Jurídicos. Rio de Janeiro: Elsevier, 2010, p. 927-945; BARBOZA, Heloisa Helena. Paternidade Responsável: o Cuidado como dever jurídico. In: Tânia da Silva Pereira; Guilherme de Oliveira (Org.). Cuidado e Responsabilidade. São Paulo: Atlas, 2011, p. 85-96; SOUZA, Vanessa Ribeiro Corrêa Sampaio. Princípio constitucional da paternidade responsável: diretrizes para a reinterpretação do art. 1614 do Código Civil. Revista Brasileira de Direito das Famílias e Sucessôes, v. 31, 2013, p. 17-39.

34 SOUZA, Vanessa Ribeiro Corrêa Sampaio. Sanções decorrentes da irresponsabilidade parental: para além da destituição do poder familiar e da responsabilidade civil, In: Civilistica.com - Revista Eletrônica de Direito Civil, a. 2, n. 2, 2013, p. 5. Disponível em: <www.civilistica.com>. Acesso 28 jun. 2017.

35 SOUZA, Vanessa Ribeiro Corrêa Sampaio. Sançôes decorrentes da irresponsabilidade parental: para além da destituição do poder familiar e da responsabilidade civil, In: Civilistica.com 
Não há óbice para o entendimento de que o princípio da parentalidade responsável também alcança e, portanto, fundamenta a responsabilidade dos envolvidos no projeto parental de modo a impor deveres em relação ao concebido in utero desde o momento da concepção. ${ }^{36}$ Ora, na medida em que o próprio ordenamento jurídico reconhece e tutela a liberdade no campo reprodutivo das pessoas que desejam concretizar o desejo de procriar, por outro lado, deveres lhes são imputados em relação ao nascituro, de maneira a assegurar os direitos deste que são merecedores de tutela. ${ }^{37}$

O princípio da paternidade (parentalidade) responsável associado ao direito ao planejamento familiar, cada vez mais, implica a assunção de responsabilidades decorrentes do exercício desse direito ${ }^{38}$. E, a partir de um projeto reprodutivo consciente e responsável, também impõe o estabelecimento de deveres aos casais, ou a homens e mulheres individualmente, para a tutela do nascituro como forma de proteção do filho a porvir. O princípio da parentalidade responsável remete ao princípio do melhor interesse da criança, ou nesse caso à salvaguarda dos direitos da futura criança, ambos com envergadura constitucional. Assegurar e promover uma vida digna à criança a porvir implica atender previamente às condições necessárias para seu melhor desenvolvimento, o que não se confunde com o tradicional

- Revista Eletrônica de Direito Civil, a. 2, n. 2, 2013, p. 5. Disponível em: <www.civilistica. com>. Acesso 28 jun. 2017.

36 Nesse sentido, Guilherme Calmon Nogueira da Gama já expôs: “O desejo de procriar, ínsito às pessoas em geral, não enfeixa apenas benefícios ou vantagens à pessoa, mas impõe a assunção de responsabilidades das mais importantes na sua vida cotidiana a partir da concepção e do nascimento do filho" (Paternidade responsável e o cuidado: algumas reflexões. In: Andréa Ferreira, Fernando G.; Galvão, Paulo Braga (Org.). Direito contemporâneo: estudos em homenagem a Sergio de Andréa Ferreira. Rio de Janeiro: De Andréa \& Morgado, 2009, p. 328). Ainda nessa linha, Vanessa Ribeiro Corrêa Sampaio Souza afirma que "a responsabilidade parental é postura imposta pela Constituição desde antes do nascimento (art. 226, $\$ 7$ ) até a maioridade do filho (art. 227 e art. 229), momento em que se presume sua autonomia para a realização de escolhas de natureza existencial e patrimonial" (Princípio constitucional da paternidade responsável: diretrizes para a reinterpretação do art. 1614 do Código Civil. Revista Brasileira de Direito das Famílias e Sucessöes, v. 31, 2013, p. 17).

37 Guilherme Calmon Nogueira da Gama ressalta que "há responsabilidade individual e social das pessoas do homem e da mulher que, no exercício das liberdades inerentes à sexualidade e à procriação, vêm a gerar uma nova vida humana cuja pessoa - a criança - deve ter priorizado o seu bem-estar físico, psíquico e espiritual, com todos dos direitos fundamentais reconhecidos em seu favor" (Princípio da paternidade responsável. In: Revista de Direito Privado, n. 18, São Paulo: RT, abr./jun., 2004, p. 30).

38 Cf. BARBOZA, Heloisa Helena. Paternidade Responsável: o Cuidado como Dever Jurídico. In: PEREIRA, Tânia da Silva (Coord.). Cuidado e Responsabilidade. São Paulo: Atlas, 2011. 
modelo de biparentalidade heterossexual. São as condições de afeto e cuidado que devem ser resguardadas, e não a manutenção de estruturas parentais convencionais.

Os princípios da dignidade da pessoa humana e da parentalidade responsável, previstos no art. $226, \mathbb{\$} 7^{\circ}$, da Constituição de 1988 , atuam, portanto, conjuntamente com o princípio do melhor interesse da futura criança. Essa tríade ao mesmo tempo em que funda e informa o direito ao planejamento familiar atua ainda como seu limite. No tocante às limitações ao direito ao planejamento familiar, Guilherme Calmon Nogueira da Gama escreveu que "no sistema jurídico-constitucional brasileiro, interesses meramente egoísticos da pessoa que pretende obter o auxílio de técnica de procriação artificial, como, por exemplo, escolher o sexo do filho, ter gêmeos ou escolher o tipo físico da criança, não podem autorizar tal prática" ${ }^{39}$ Há que assinalar, ainda, que os limites atuam não somente quando o exercício do direito ao planejamento familiar ocorre através das técnicas de reprodução assistida.

Assim, o reconhecimento e a afirmação dos direitos ligados à sexualidade e à reprodução, no plano internacional ou interno, reforçam as responsabilidades decorrentes do exercício cada vez mais livre daqueles, mas que devem ser exercidos com autonomia e informação. O livre planejamento familiar enseja o reconhecimento da liberdade de decisão a respeito do desejo de se ter filhos, do número e espaçamento entre eles. A liberdade reprodutiva implica, portanto, a assunção de responsabilidades resultantes do exercício do direito ao planejamento familiar e deve necessariamente ser interpretada dentro do contexto de solidariedade familiar estabelecida pelo constituinte de 1988.

\section{A FAMÍLIA CONTEMPORÂNEA E AS NOVAS FORMAS DE PARENTALIDADE}

Da decretação de seu fim à atual defesa e promoção da familiaridade, agora calcada na comunhão de afeto, deslocada a valor central a sua constituição e caracterização na órbita jurídica, outros são os princípios informadores dos relacionamentos inseridos no contexto da vida familiar. De sua democratização à pluralização, passando pela igualdade entre os cônjuges e filhos e o prioritário interesse das crianças e adolescentes, antigas reivindicações e agora estabelecidas constitucionalmente, defluem-se alterações estruturais na família contemporânea. Segundo

39 GAMA, Guilherme Calmon Nogueira. Paternidade responsável e o cuidado: algumas reflexões. In: Andréa Ferreira, Fernando G.; Galvão, Paulo Braga (Org.). Direito contemporâneo: estudos em homenagem a Sergio de Andréa Ferreira. Rio de Janeiro: De Andréa \& Morgado, 2009, p. 317-338. 
Elizabeth Roudinesco, a família é atualmente "reivindicada como o único valor seguro ao qual ninguém quer renunciar. Ela é amada, sonhada e desejada por homens, mulheres e crianças de todas as idades, de todas as orientações sexuais e de todas as condições". ${ }^{40}$

Desse modo, se, por um lado, os avanços da biotecnociência foram responsáveis por profundas alterações nas relações familiares contemporâneas, por outro, seria excesso lhes imputar todas as modificações sofridas pela família moderna, como o divórcio, as uniões homoafetivas e a monoparentalidade. Ao contrário, o surgimento da reprodução assistida que, num primeiro momento, seria capaz de ampliar os meios de constituição da família monoparental e pluriparental, antes restritos às vicissitudes da vida, parece não ter surtido impacto social relevante. Assim, a possibilidade de constituição de famílias monoparentais através da utilização individual pelas pessoas das técnicas de reprodução assistida ou de famílias multiparentais não foi imediatamente acatada pela sociedade, o que, por sua vez, refletiu na frenagem pelo direito no uso dessas tecnologias para esses fins.

No atual cenário de democratização e valorização da afetividade, a família contemporânea se desvinculou da necessidade de relações conjugais, como o casamento, para a constituição de núcleos familiares, permitindo que novas famílias se baseiem exclusivamente em relaçóes de parentalidade, como os exemplos da monoparentalidade e da multiparentalidade. Indispensável examinar, portanto, as formas de constituição das famílias baseadas em relações de parentalidade como legítimo exercício do direito ao planejamento familiar constitucionalmente assegurado.

\subsection{A monoparentalidade planejada através da reprodução assistida $^{41}$}

A Constituição da República de 1988, em seu art. 226, parágrafo 4ㅇ, prevê a comunidade formada pelos ascendentes e seus descendentes - as chamadas famílias monoparentais. A rigor, essa forma de estrutura familiar sempre existiu, no entanto, além de não ter o reconhecimento jurídico e estatuto específico, este último inexistente até hoje ${ }^{42}$, sempre esteve reservado à imprevisibilidade dos acon-

40 ROUDINESCO, Elizabeth. A Família em Desordem. Rio de Janeiro: Nova Fronteira, 2002, p. 198.

41 Os argumentos aqui expostos foram desenvolvidos em ALMEIDA, Vitor. Planejando a família in vitro: o direito ao planejamento familiar e as famílias monoparentais. Disponível em: http://www.ibdfam.org.br. Acesso em: 10 mar. 2018.

42 "Enquanto o Direito Civil não institui a família monoparental como sujeito de direito, o poder público não se vê compelido a auxiliá-la. Não reconhecida, não é levada em consideração, o 
tecimentos da vida. E, mesmo após mais de duas décadas de seu reconhecimento em sede constitucional, a doutrina ainda é reticente em aceitar o planejamento destas entidades familiares, sob o argumento de que permitir sua constituição artificialmente, ou seja, por opção livre e consciente do genitor individual, seria uma forma de estimular a sua formação, o que não seria o objetivo do dispositivo constitucional.

Neste sentido, Eduardo de Oliveira Leite entende ser "precipitado e equivocado [invocar o] art. 226, parágrafo $4^{\circ}$ do texto constitucional como argumento legitimador da inseminação artificial da mulher solteira, separada ou divorciada", pois defende que "o dispositivo constitucional, de forma louvável, apenas inseriu na esfera da proteção estatal, as famílias 'monoparentais'; em momento algum as reconheceu com vistas a proliferação das mesmas” (LEITE, 1995, p. 356). Registra, ainda, Guilherme Calmon Nogueira da Gama que "a Constituição não estimula a formação de famílias monoparentais, mas as reconhece" (GAMA, 2000, p. 359).

Ainda existe resistência na doutrina nacional em autorizar que a pessoa solteira que faz uso da procriação artificial como legítima hipótese de causas constitutivas da monoparentalidade, sendo comum encontrar resistência ainda maior quando se trata do homem solteiro elegível, em razão da necessidade do recurso à gestação de substituição, assunto ainda longe de consenso político-social e já fortemente restringido pela resolução CFM n. 2.168/2017.33

Aponta Demian Diniz da Costa que "de uma forma geral, alguns aspectos, ou melhor, algumas causas de monoparentalidade são encontradas em diversas sociedades, tornando-se comum entre diversos países, como, por exemplo, a viuvez, o celibato, o divórcio e a separação". No entanto, ressalva o autor que "a monoparentalidade planejada merece especial atenção", como nos casos de adoção e uso de técnicas de reprodução assistida, restringindo, contudo, às hipóteses de mulheres

que tende a agravar seu caráter discriminatório no meio social”. LEITE, Eduardo de Oliveira. Famílias monoparentais. 2. ed., São Paulo: RT, 2003, p. 330.

43 "VII - SOBRE A GESTAÇÃO DE SUBSTITUIÇÃO (CESSÃO TEMPORÁRIA DO ÚTERO) As clínicas, centros ou serviços de reprodução assistida podem usar técnicas de RA para criarem a situação identificada como gestação de substituição, desde que exista um problema médico que impeça ou contraindique a gestação na doadora genética, em união homoafetiva ou pessoa solteira. 1 . A cedente temporária do útero deve pertencer à família de um dos parceiros em parentesco consanguíneo até o quarto grau (primeiro grau -mãe/filha; segundo grau -avó/irmã; terceiro grau -tia/sobrinha; quarto grau -prima). Demais casos estão sujeitos à autorização do Conselho Regional de Medicina.2. A cessão temporária do útero não poderá ter caráter lucrativo ou comercial." 
solteiras ${ }^{44}$. Sempre se restringiu, portanto, as causas de constituição da família monoparental às hipóteses decorrentes dos infortúnios da vida e não de uma decisão autônoma e consciente. No entanto, o reconhecimento da autonomia reprodutiva no ordenamento brasileiro reforça a possibilidade de formação da família monoparental desvinculada da ideia de circunstâncias alheias da vida, circunscrevendo-a no campo da liberdade de escolhas de cada pessoa, admitindo-se, portanto, a elegibilidade individual à reprodução assistida como forma de constituição de uma entidade familiar.

Assim, diante da tutela da autonomia reprodutiva, assentada na recente afirmação histórica dos direitos reprodutivos e sexuais no campo dos direitos humanos fundamentais, e, por conseguinte, da ampliação do alcance do direito ao planejamento familiar ao aspecto conceptivo ${ }^{45}$, não é mais razoável limitá-los com base no o direito à biparentalidade, que tem por fundamento a matriz convencional do modelo binário heterossexual. Não é possível, à luz dos valores constitucionais, a afirmar que a biparentalidade integra o conteúdo do princípio do melhor interesse da criança, especialmente face à inexigibilidade nos casos de adoção. ${ }^{46}$

Durante a vigência da Resolução n. 1358/92, no que concerne aos usuários das técnicas de reprodução assistida ${ }^{47}$, a doutrina se posicionava no sentido de

44 COSTA, Demian Diniz da. Famílias monoparentais: reconhecimento jurídico. Rio de Janeiro: AIDE, 2002, p. 31, 36 e 45-49.

45 A interpretação do art. $1^{\circ}$ cominado com os artigos $3^{\circ}$, parágrafo único, I e $9^{\circ}$ da Lei n. 9.263, de 12 de janeiro de 1996, de uma vez por todas, superou a restrição conceitual calcada no seu aspecto contraceptivo. Observa, no entanto, Heloisa Helena Barboza que “[...] à semelhança do verificado em outros países, predominam as ações voltadas para a anticoncepção: as políticas e plenos governamentais têm sido notoriamente direcionados para o aspecto negativo do planejamento familiar" (Reprodução humana como direito fundamental. In: Carlos Alberto Menezes Direito; Antônio Augusto Cançado Trindade; Antônio Celso Alves Pereira. (Org.). Novas Perspectivas do Direito Internacional Contemporâneo. Rio de Janeiro: Renovar, 2008, p. 785).

46 Art. 42. Podem adotar os maiores de vinte e um anos, independentemente de estado civil. Em 03 de agosto de 2009, com a promulgação da Lei n. 12.010, foi alterado este dispositivo do Estatuto da Criança e do Adolescente, que com a nova redação está em consonância com a redução da maioridade civil estabelecida no art. $5^{\circ}$ do Código Civil de 2002, nos seguintes termos: "Art. 42. Podem adotar os maiores de 18 (dezoito) anos, independentemente do estado civil".

47 Nos termos da Resolução CFM n. 1.358/1992, II, 1 e 2: "II - USUÁRIOS DAS TÉCNICAS DE RA. 1 - Toda mulher, capaz nos termos da lei, que tenha solicitado e cuja indicação não se afaste dos limites desta Resolução, pode ser receptora das técnicas de RA, desde que tenha concordado de maneira livre e consciente em documento de consentimento informado. 2 Estando casada ou em união estável, será necessária a aprovação do cônjuge ou do companheiro, após processo semelhante de consentimento informado". 
somente permitir que mulheres casadas ou em união estável se submetam à reprodução artificial, de modo a evitar o risco de posterior ausência do vínculo pater$\mathrm{no}^{48}$. Rose Melo Venceslau Meireles entende que "acolher a possibilidade de uma pessoa ser concebida sem pai, é frustrá-la do convívio familiar e, principalmente, afrontar a sua dignidade. A criança tem direito à biparentalidade", refutando a possibilidade de argumentação com base na proteção às família monoparentais, "pois o que se pretende com a norma do $\$ 4^{\circ}$ do art. 226 da CF é que também tenham proteção do Estado, uma vez que venham a se formar tais circunstâncias. Diferencia-se a hipótese do legislador estimular certas situações, daquela em que se protege uma situação em que venha ocorrer, como na concretização da família monoparental”49. Segundo Guilherme Calmon Nogueira da Gama:

Não há como reconhecer, em regra, o direito à reprodução em relação à pessoa sozinha, levando em conta especialmente o princípio do melhor interesse da (futura) criança que, privada do pai ou da mãe, se sujeitaria à estrutura familiar parcial, tornando-a desigual em relação às demais pessoas desde o momento da concepção. Tal regra, no entanto, não deve ser absoluta, especialmente à luz da ordem civil constitucional instaurada em 1988 no direito brasileiro. A lei n. 9263/96, no seu artigo 3o autoriza a monoparentalidade na reprodução assistida, desde que observados, no caso concreto, os princípios constitucionais relacionados ao planejamento familiar e à assistência do Poder Público, além da própria esterilidade da pessoa (GAMA, 2003, p. 1008).

Resistências à parte de relegar a formação da monoparentalidade somente a causas imprevisíveis, desde a promulgação do Estatuto da Criança e do Adolescente - Lei 8.069/90 - se reconheceu a possibilidade de planejamento da formação da comunidade monoparental, em virtude da não restrição às pessoas solteiras, maiores e capazes, voluntariamente e deliberadamente constituírem um vínculo paterno-filial através da adoção. Uma das possíveis explicações assenta-se no caráter de solidariedade social geralmente atribuído ao ato de adoção, enquanto que na procriação artificial opera-se o inverso, como se fosse um ato egoístico gerar um filho sem lhe possibilitar, ainda que futuramente, o reconhecimento da paternidade/ maternidade.

É claro que ao se reconhecer o direito à reprodução são indispensáveis que se considerem os direitos fundamentais da criança, mesmo que ainda não concebidas

48 Neste sentido, se posicionam: FACHIN, Luiz Edson. Direito de Família: elementos críticos à luz do novo código civil brasileiro. 2. ed., Rio de janeiro: Renovar, 2003 p. 256; BARBOZA, Heloisa Helena. A filiação em face da inseminação artificial e da fertilização "in vitro". Rio de Janeiro: Renovar, 1993, p. 67 a 72 e 113.

49 VENCELAU, Rose Melo. O elo perdido da filiação: entre a verdade jurídica, biológica e afetiva no estabelecimento do vínculo paterno-filial. Rio de Janeiro: Renovar, 2004, p. 56. 
ou nascidas, estabelecidos, no plano internacional, na Convenção Internacional dos Direitos da Criança e do Adolescente da Organização das Nações Unidas e, na ordem interna, no Estatuto da Criança e do Adolescente, visto que a decisão sobre procriar ou não interfere de modo decisivo na esfera de interesses do filho a porvir. Que tal confrontação deve necessariamente ser harmonizada não resta maiores dúvidas, em virtude da proteção antecipada ao desenvolvimento da personalidade da futura criança. No entanto, o que se debate é a controversa existência do direito da futura criança à biparentalidade, e se este deve integrar o princípio do melhor interesse da criança. A própria convenção, em seu art. 7º, afirma que: "a criança deve ser registrada ao nascimento a ter direito a um nome, e o direito a adquirir uma nacionalidade e, na medida do possível, tem o direito de conhecer seus pais e de se criada por eles", reconhecendo, assim, a importância da convivência familiar caracterizada pela "triangularização" do vínculo paterno-filial. No entanto, mitiga tal imposição ao aceitar que nem sempre é possível e, muito menos, indispensável a dupla figura parental. ${ }^{50}$

Assim, apesar preponderância dos interesses da futura criança, esta deve ser entendida como a capacidade de fornecer todas as condições necessárias para que o filho se desenvolva com dignidade e afeto, não havendo incompatibilidade entre o princípio do melhor interesse da criança e a monoparentalidade planejada. $\mathrm{O}$ próprio texto constitucional ao expressar que o direito ao planejamento familiar funda-se nos princípios da dignidade da pessoa humana e da paternidade (parentalidade) responsável, ao mesmo tempo em que impõe a relatividade dos interesses do indivíduo que deseja gerar, em respeito aos direitos da futura criança, exige também que se não restrinja os direitos do eventual genitor única e exclusivamente em razão de seu estado civil, posto que a falta de "triangularização" tradicional da relação parental não enseja, por si só, prejuízos ao filho planejado.

O debate a respeito da legitimidade do emprego das técnicas de reprodução assistida como via de formação de uma família perpassa a questão do reconhecimento do direito à procriação ${ }^{51}$, que até pouco tempo atrás sempre fora visto como

50 BRAUNER, Maria Claudia Crespo. Monoparentalidade projetada e o direito do filho à biparentalidade. In: Estudos Jurídicos, São Leopoldo, v. 31, n. 83, setembro/dezembro, 1998, p. 151.

51 Heloisa Helena Barboza, em obra pioneira sobre o assunto, já alertava que a questão do direito a se ter filhos "não tem natureza meramente teórica, visto que tal definição imporá os rumos que se devam dar à matéria", argumentando que "se entendido como direito fundamental, não há que se criar qualquer impedimento às técnicas que resultem na ausência de um dos genitores, como ocorre na inseminação artificial de mulheres solteira" (A filiação em face da inseminação artificial e da fertilização "in vitro". Rio de Janeiro: Renovar, 1993, p. 37-38). 
mera faculdade ${ }^{52}$. Relata Heloisa Helena Barboza, com base nos ensinamentos de Encarna Roca i Trías, que já na década de oitenta do século passado, época de expansão no uso das técnicas de reprodução medicamente assistida, mais precisamente no ano de 1987, em "[...] consulta ao Comitê Diretor dos Direitos Humanos $(\mathrm{CDDH})$ sobre a existência ou não do direito de procriar, mais precisamente sobre a garantia, na Carta Europeia, de um direito absoluto de procriar, incluído no direito à vida”, obteve-se uma resposta negativa do Comitê. Nesse sentido, reconhece a autora que "em sentido estrito, nem a Comunidade Europeia, nem Declarações e Convênios Internacionais, reconhecem explicitamente o direito de procriação como tal, mas apenas o 'de fundar uma família". 53

No Brasil, a Lei n. 9.263, de 12 de janeiro de 1996, que regulamentou o art. 226, parágrafo $7^{\circ}$ da Constituição de 1988, reconheceu como direito de todo cidadão, em conjugalidade ou não, o direito ao planejamento familiar, não permitindo, portanto, fazer ressalvas acerca das pessoas elegíveis às técnicas de reprodução assistida, mesmo que individualmente consideradas e com finalidade de formação da família monoparental, de forma planejada e consciente. Ademais, ao incluir "a assistência à concepção e contracepção", devendo, para tanto, serem oferecidos "todos os métodos e técnicas [...] cientificamente aceitos e que não coloquem em risco a vida e a saúde das pessoas, garantida a liberdade de opção", nos respectivos artigos $3^{\circ}$, parágrafo único, I e $9^{\circ}$, permitiu que se incluíssem as novas tecnologias reprodutivas como possíveis recursos à concepção.

Desse modo, a afirmação da autonomia reprodutiva dentro do ordenamento jurídico nacional, mesmo que por via oblíqua, e o reconhecimento do aspecto conceptivo (ou positivo) do direito ao planejamento familiar embasam a existência de um direito à procriação, que embora ainda questionável seu status jurídico dentro do ordenamento pátrio, se mera faculdade, direito individual ou direito fundamental, tendenciosa tem sido a doutrina em acatar o último enquadramento. $\mathrm{O}$ que,

52 Sustenta Eduardo de Oliveira Leite que "Este 'direito' invocado é apenas uma faculdade, ou melhor, uma liberdade. Catherine Labrusse-Rieu e J. L. Baudoin jé se referiram sobre a matéria em termos bastante claros. Existe uma liberdade de engendrar filhos. Quando a natureza se opõe, o direito médico e social criaram um verdadeiro direito à cura da esterilidade tentando vencer este handicap e permitindo o exercício da liberdade de procriar. Entretanto, procriar não é um direito. [...]" (Procriaçôes artificiais e o direito: aspectos médicos, religiosos, psicológicos, éticos e jurídicos. São Paulo: RT, 1995, p. 356).

53 BARBOZA, Heloisa Helena. Reprodução humana como direito fundamental. In: Carlos Alberto Menezes Direito; Antônio Augusto Cançado Trindade; Antônio Celso Alves Pereira. (Org.). Novas Perspectivas do Direito Internacional Contemporâneo. Rio de Janeiro: Renovar, 2008, p. 780-781. 
em princípio, poderia aparentar um locus normativo condizente com a tutela da reprodução humana pretendida, e, consequentemente, traduzir-se em proteção adequada, não tem alterado substancialmente os limites jurídicos do exercício desse direito, eis que o colocam dentre os direitos humanos fundamentais mais relativizados $^{54}$ frente à colisão com os demais, restando-lhe posição desprivilegiada na ponderação destes, em que pese a sua consideração como uma das manifestações dos direitos fundamentais.

Desde a Resolução CFM n. 1.957/2010 que foi ampliado os sujeitos receptores destas técnicas para "todas as pessoas capazes", o que se manteve nas resoluções posteriores, como a Res. 2.013/2013, bem como na Res. 2.121/2015 e, finalmente, na Resolução n. 2.168/2017, atualmente em vigor, que dispõe que todas as pessoas capazes, que tenham solicitado o procedimento e cuja indicação não se afaste desta resolução, podem ser receptoras das técnicas de RA", sendo permitido o uso para relacionamentos homoafetivos e pessoas solteiras, desde que todos os participantes tenham consentido de forma esclarecida e informada. Desse modo, ressalta Debora Diniz que foi preciso uma espera de "quase duas décadas para afirmar publicamente que o desejo de filhos é algo comum a todas as pessoas", ou seja, "um homem sozinho, uma mulher lésbica, uma travesti ou uma pessoa intersexo, qualquer uma delas pode ter seu desejo de filhos realizado com o auxílio das técnicas médicas". 55

O principal mérito das resoluçóes acima citadas, em razão de ser uma ferramenta voltada precipuamente aos médicos, reside em fornecer parâmetros éticos na atuação médica, conscientizando-os que o desejo de filhos não é restrito aos casais heterossexuais, mas pelo contrário, estendem-se às demais pessoas, independentemente do estado civil e opção sexual. Mesmo que através de uma norma ética, concede segurança à equipe médica, que se encontra respaldada por uma diretriz emanada de seu próprio órgão de classe. Neste sentido, pelo menos, em princípio, "um médico de medicina reprodutiva não poderá se recusar a atender um casal de

54 Defende Heloisa Helena Barboza que "o reconhecimento do direito à reprodução, em seus aspectos positivo e negativo, não pode conferir-lhe caráter absoluto" (Reprodução humana como direito fundamental, cit., p. 786). Guilherme Calmon Nogueira da Gama também sustenta que o "[...] direito à reprodução não é absoluto - como nenhum direito fundamental também não o é - e, desse modo, somente deve ser exercido dentro dos limites que lhe são impostos pelo próprio ordenamento" ( $A$ nova filiação: o biodireito e as relaçóes parentais: o estabelecimento da parentalidade - filiação e os efeitos jurídicos da reprodução assistida heteróloga. Rio de Janeiro: Renovar, 2003, p. 723).

55 DINIZ, Debora. Desejo de filhos. Folha de São Paulo, São Paulo, 28 jan. 2011. 
mulheres lésbicas ou um homem sozinho que faça uso de uma gravidez de substituição para ter filho". ${ }^{56}$

É inquestionável o avanço das normas de caráter deontológico, que ampliaram significativamente os pacientes das técnicas de reprodução assistida no Brasil, desvinculando-se, a princípio, da exigência de biparentalidade heterossexual. Embora direcionada aos médicos que atuam na área da reprodução assistida, as resoluções são relevantes na medida em que há décadas se espera por uma regulamentação ordinária sobre o tema no ordenamento jurídico. No entanto, por inércia do legislador brasileiro, se aglomeram os projetos de lei em trâmite no Congresso Nacional.

Desse modo, em que pese uma interpretação mais condizente com os preceitos constitucionais permitisse a possibilidade de ampliar o rol de pacientes das técnicas artificias procriativas antes da mudança no posicionamento do CFM, não se pode descurar da importância desta norma deontológica no sentido de respaldar uma atuação médica sem preconceitos. Neste sentido, escreveu Debora Diniz que como "um homem sozinho ou uma mulher gay em união estável não eram acolhidos pela antiga resolução, [...] os médicos poderiam se sentir intimidados em atendê-los pelo risco de um processo ético no conselho". ${ }^{57}$

No entanto, não se devem recepcionar as resoluções do CFM como diretrizes extremadas, concedendo um caráter quase que absoluto ao direito à reprodução, tendo em vista que há outros valores em jogo, e estes devem merecer a devida atenção em um ordenamento unitário e que encontra na Constituição seu fundamento e sua tábua axiológica a guiar e condicionar toda a legislação infraconstitucional. Desse modo, a Resolução n. 2.168/2017 afigura-se como um instrumento hábil a direcionar a atuação dos médicos, tendo, acertadamente, ampliado os sujeitos elegíveis às técnicas de reprodução assistida. Não cabe ao médico eleger quem são as pessoas legitimadas a se submeterem ao recurso da medicina reprodutiva, discriminando os pleiteantes em virtude do estado civil ou da opção sexual. Mas é papel do direito, a partir dos comandos constitucionais, realizar o equacionamento dos valores envolvidos, de modo a respeitar à autonomia reprodutiva e o direito ao planejamento familiar, ao mesmo tempo em que se asseguram os direitos do filho a porvir.

\subsection{O reconhecimento jurídico da multiparentalidade planejada}

O fenômeno da multiparentalidade - ou pluriparentalidade - consiste na multiplicidade de liames parentais formados por laços biológicos e/ou socioafetivos

56 DINIZ, Debora. Desejo de filhos. Folha de São Paulo, São Paulo, 28 jan. 2011.

57 DINIZ, Debora. Desejo de filhos. Folha de São Paulo, São Paulo, 28 jan. 2011. 
construídos por motivos anteriores ou supervenientes ao nascimento de determinada pessoa e que compartilham da vivência parental sem que seja necessária a substituição de um vínculo pelo outro ${ }^{58}$. Tal composição familiar é bastante comum como consequência das famílias recompostas ou de outras composições decorrentes da parentalidade socioafetiva, apresentando-se como efeito das relações de afeto e cuidado forjadas ao longo da infância e da juventude, admitindo-se, inclusive, que tais laços sejam construídos na fase adulta. Nada impede, contudo, que a pluralidade de vínculos parentais se estabeleça de forma planejada por três ou mais pessoas que desejam desde o início do projeto parental compartilhar dessa experiência.

O Plenário do Supremo Tribunal Federal (STF) fixou tese de repercussão geral que assume caráter histórico no direito brasileiro ao julgar o Recurso Extraordinário n. 898.060, em 22 de setembro de 2016. A suprema Corte afirmou que "a paternidade socioafetiva, declarada ou não em registro público, não impede o reconhecimento do vínculo de filiação concomitante baseado na origem biológica, com os efeitos jurídicos próprios" (Repercussão Geral 622). Com isso, reconheceu definitivamente o fenômeno da multiparentalidade no sistema jurídico brasileiro $^{59}$, minando as resistências jurídicas e culturais calcadas no modelo biparental

58 Segundo Anderson Schreiber e Paulo Franco Lustosa: "A multiparentalidade pode ser conceituada em acepção ampla ou em acepção estrita. A multiparentalidade lato sensu consiste no reconhecimento, pelo ordenamento jurídico, de que uma pessoa tenha mais de um vínculo parental paterno ou mais de um vínculo parental materno. Para a sua configuração, é suficiente que alguém tenha dois pais ou duas mães, o que abarca não apenas os arranjos multiparentais que, por circunstâncias e fundamentos diversos, envolvam duas mães e um pai, dois pais e uma mãe, e assim por diante, mas também os casos de simples biparentalidade homoafetiva, em que a distinção de gênero afigura-se, a rigor, inaplicável. É nessa acepção ampla que o fenômeno costuma ser estudado no Brasil. Já em acepção restrita, a multiparentalidade pode ser definida como o reconhecimento jurídico de mais de dois vínculos de parentalidade à mesma pessoa. Em outros termos, a expressão estaria reservada às hipóteses em que alguém tenha três ou mais laços parentais, não abrangendo, portanto, a mera dupla paternidade ou dupla maternidade se desacompanhada do terceiro ascendente, que resultaria na configuração de mais de dois vínculos parentais. São casos de multiparentalidade stricto sensu, por exemplo, aqueles em que uma pessoa tem duas mães e um pai, dois pais e uma mãe, três mães, dois pais e duas mães, e assim sucessivamente. Note-se que tal acepção se revela mais adequada ao significado das expressões multiparentalidade e pluriparentalidade, cujos prefixos exprimem noção de muitos, em contraposição à biparentalidade" (Efeitos jurídicos da multiparentalidade. In: Pensar, Fortaleza, v. 21, n. 3, p. 847-873, set./dez. 2016, p. 851).

"O desafio está posto: ele consiste em ultrapassar o legado reducionista que contamina o direito codificado - um pai, uma mãe - e a redimensionar as possibilidades normativas contidas no universo das relações pluriparentais, fortalecendo as realidades familiares e estimulando a assunção de responsabilidades, atentando, assim, às necessidades de um ser humano concreto - pensado como ser no mundo - e para a centralidade por ele ocupada em um sistema jurídico 
orientador da família nuclear - constituída pelo pai, pela mãe e pelo(s) filho(s). Segundo Anderson Schreiber, a decisão da corte permitiu ainda o reconhecimento do "instituto da paternidade socioafetiva mesmo à falta de registro - tema que ainda encontrava resistência em parte da doutrina de direito de família”, bem como "afirmou que a paternidade socioafetiva não representa uma paternidade de segunda categoria diante da paternidade biológica". ${ }^{60}$

A decisão é fruto de nítida e acelerada transformação vivenciada pelo direito das famílias após a promulgação da Constituição de 1988, que fincou as bases para uma renovada concepção jurídica da esfera familiar, que se apresenta como ambiente plural, igualitário, democrático e funcionalizado à promoção da personalidade dos seus integrantes. A rigor, a Constituição não veda a constituição de vínculos parentais plurais. Pelo contrário, o fenômeno da multiparentalidade concretiza relevante princípio constitucional de plena igualdade de direitos entre os filhos (art. 227, $\$ 6^{\circ}$ ), que pró́be quaisquer designações discriminatórias relativas à filiação, como igualmente veda qualquer caráter hierárquico, a priori, que se estabeleça entre os critérios de fixação da parentalidade, quer se trate de parentalidade biológica, socioafetiva ou jurídica (presumida). Cuida-se, ainda, de importante valorização da socioafetividade nas relações familiares, na medida em que supera o modelo binário parental heterossexual em prol de um arranjo que permite um complexo de relações funcionalizados à proteção e ao desenvolvimento da personalidade do filho de múltiplos pais.

Antes da festejada decisão, apesar do movimento de parcela da doutrina no sentido de reconhecer o fenômeno da pluripareantalidade ${ }^{61}$, alguns autores já questionaram sua constitucionalidade, ao sustentarem a afronta ao melhor interesse da criança e do adolescente, e no campo jurisprudencial já se afastou o reconhecimento com base em argumentos de caráter moral ${ }^{62}$. Todavia, o reconhecimento jurídico

(FACHIN, 2006, p. 14-15) que pretende ser democrático e de direito”. CATALAN, Marcos. Um ensaio sobre a multiparentalidade: explorando no ontem pegadas que levarão ao amanhã. Revista da Faculdade de Direito - UFPR, Curitiba, n. 55, 2012, p. 153.

60 SCHREIBER, Anderson. STF, Repercussão Geral 622: a Multiparentalidade e seus Efeitos. Disponível em: <http://www.cartaforense.com.br/conteudo/artigos/stf-repercussao-geral-622-a-multiparentalidade-e-seus-efeitos/16982>. Acesso em: 13 mar. 2018.

61 V., por todos, TEIXEIRA, Ana Carolina Brochado; RODRIGUES, Renata de Lima. O direito das famílias entre a norma e a realidade. São Paulo: Atlas, 2010, p. 190-218; CASSETARI, Christiano. A multiparentalidade e parentalidade socioafetiva: efeitos jurídicos. São Paulo: Atlas, 2014.

62 O Tribunal de Justiça do Rio Grande do Sul já sustentou que "não podem coexisitir duas paternidades sobre uma pessoa. Isto sim confundiria, isto sim afrontaria o direito da personalidade" (TJRS, Apelação Cível n. 70017530965, 8ª Câmara, Rel. Des. José S. Trindade, julg. 28 jun. 2007). 
de múltiplos laços parentais, via de regra, atende ao princípio do melhor interesse da criança, uma vez que reflete à sua realidade nas hipóteses de constituição superveniente com a atribuição da função parental àqueles que já a exercem, bem como atende aos futuros interesses do filho nos casos de multiparentalidade planejada com o reconhecimento do status de filiação a todos os envolvidos no projeto parental com a produção dos efeitos inerentes a tal estado. A tese firmada pelo STF, portanto, permitiu a superação das barreiras ao reconhecimento da multiparentalidade como fenômeno familiar presente na nossa sociedade e que merece proteção jurídica, independentemente da estrutura codificada familiar, sem impor modelos estanques e pré-concebidos de entidades familiares.

Nesse particular, avulta como importante avanço na aproximação entre o Direito de família e a realidade social, que andaram durante tanto tempo afastadas. O fenômeno da multiparentalidade finalmente deixou de ser um fato social ignorado pelo direito, eis que se reconheceu a existência de múltiplos laços parentais aptos a gerar os efeitos jurídicos decorrentes do vínculo paterno-filial, sem o estabelecimento de prévia hierarquia entre os critérios de parentalidade e sem a exclusão dos vínculos já existentes, que somente podem ser examinados à luz das circunstâncias do caso concreto de modo a estabelecer se é hipótese ou não de pluriparentalidade. Tal verificação é de todo importante para afastar os pedidos de reconhecimento de vínculo parental motivado por interesses puramente patrimoniais ${ }^{63}$. A multiparentalidade é um fenômeno que decorre da atual dinâmica das famílias, que não mais se encaixam no artificial arranjo codificado legalmente.

No entanto, embora o Supremo Tribunal Federal brasileiro tenha reconhecido a possibilidade de multiparentalidade, diversas questóes jurídicas permanecem em aberto, como, por exemplo, os efeitos sucessórios na hipótese de o filho falecer

63 Segundo Anderson Schreiber: "Há, ainda, o generalizado receio de que a posição adotada pelo STF possa gerar demandas mercenárias, baseadas em puro interesse patrimonial. Argumenta-se que a corte teria aberto as portas do Judiciário para filhos que somente se interessam pelos pais biológicos no momento de necessidade ou ao se descobrirem como potenciais herdeiros de fortunas. Nesse particular, competirá aos juízes e tribunais separar, como sempre, o joio do trigo, empregando os mecanismos disponíveis na ordem jurídica brasileira para se evitar o exercício de uma situação jurídica subjetiva em descompasso com seu fim axiológico-normativo. O abuso do direito e a violação à boa-fé objetiva têm plena aplicação nesse campo, sendo de se lembrar que são instrumentos que atuam não apenas no interesse particular, mas também no interesse público de evitar a manipulação de remédios que são concedidos pelo ordenamento não de modo puramente estrutural, mas sempre à luz de uma finalidade que se destinam a realizar" (STF, Repercussão Geral 622: a Multiparentalidade e seus Efeitos. Disponível em: <http://www.cartaforense.com.br/conteudo/artigos/stf-repercussao-geral-622-a-multiparentalidade-e-seus-efeitos/16982 >. Acesso em: 13 mar. 2018). 
antes de seus múltiplos pais, ou, ainda, como se aplicam os direitos de guarda e visitação em casos de multiparentalidade ${ }^{64}$. Tais desafios são lançados aos intérpretes do Direito em razão de se manusear um arcabouço jurídico moldado para as famílias nucleares heterossexuais, que não se volta para a nova realidade das famílias. Por isso, o reconhecimento de múltiplos vínculos parentais pelo ordenamento jurídico constitui importante instrumento de proteção a interesses relevantes merecedores de tutela no plural mosaico parental, outrora não abrigado pelo Direito.

Contudo, a multiplicidade de liames parentais aumenta a probabilidade, em diversas situações fáticas, de colisão entre os interesses merecedores de tutela, a qual deve ser sempre guiada pelo melhor interesse da criança e do adolescente em sua prioritária e integral proteção. Apesar de não haver hierarquia entre as formas de parentalidade, na linha da decisão do STF, nem sempre a coexistência de vínculos parentais será a melhor solução, eis que multiparentalidade não deve ser forçada, eis que construída no contexto fático do mosaico familiar, podendo ser o caso de necessária substituição que exclua algum liame parental existente. No entanto, na hipótese de multiparentalidade por opção, todos os envolvidos são obrigados a cumprirem com os deveres inerentes à função parental, eis que a parentalidade responsável decorre da livre e consciente decisão sobre a liberdade de procriar, ou seja, de constituir família, com a assunção, portanto, das obrigações impostas por lei.

Em outros termos, a multiparentalidade pode decorrer dos laços de socioafetividade construídos pela convivência entre pais e filhos, registrais ou não, bem como do legítimo exercício do direito ao planejamento familiar, ancorado na autonomia reprodutiva, que impõe que o exercício da parentalidade responsável desde o início da concepção do futuro filho. Em ambos os casos, a multiparentalidade é expressão da mais genuína liberdade de constituir o modelo familiar que melhor atende às aspiraçôes existenciais de cada indivíduo.

\section{CONSIDERAÇÕES FINAIS}

A autonomia reprodutiva deve ser encarada como um dos espaços mais íntimos da pessoa humana, domínio pertencente à reserva de intimidade dos sujeitos ou de casais, ainda que se reporte a eleição da via conceptiva artificial para a concretização do projeto parental. Nessa esteira, a tutela jurídica a incidir deve ser capaz de assegurar a dignidade e integridade psicofísica dos envolvidos - os que

64 Sobre os efeitos da multiparentalidade, cf. SCHREIBER, Anderson; LUSTOSA, Paulo Franco. Efeitos jurídicos da multiparentalidade. In: Pensar, Fortaleza, v. 21, n. 3, p. 847-873, set./ dez. 2016. 
desejam gerar e os que serão gerados, o que não se confunde com obrigatoriedade de biparentabilidade heterossexual.

O reconhecimento dos direitos reprodutivos como direitos humanos fundamentais na esfera internacional e do direito ao planejamento familiar, estabelecido no art. 227, $\$ 6^{\circ}$ da Constituição da República de 1988, fortalece o reconhecimento do princípio da autonomia reprodutiva, que, por sua vez, reforça a existência de um direito fundamental à reprodução, e, ambos, respeitados os princípios da liberdade e da igualdade, não permitem a restrição, com base em gênero ou formas de conjugalidade, à utilização das técnicas de reprodução assistida, descabendo, portanto, a limitação, em razão única e exclusivamente do estado civil, sobretudo quando houver induvidosa intenção de constituir uma família, ainda que seja monoparental ou multiparental.

Além disso, a nova concepção da família contemporânea contempla uma visão instrumental das estruturas familiares, concebendo uma diversidade de entidades familiares, todas voltadas às exigências humanas existenciais. Desse modo, o ato de reprodução não deve se restringir aos desejos individuais, no entanto, o direito à reprodução por meio de técnicas de reprodução assistida também não deve ser restringido em função de uma visão ultrapassada da necessidade de biparentalidade heterossexual para o desenvolvimento da personalidade da futura criança, ainda a ser concebida.

Os desafios da monoparentalidade e da multiparentalidade planejada descortinam a superação do paradigma da sacralidade da família nuclear, calcada no modelo biparental. As perplexidades, contudo, devem ser superadas em prol da plena efetivação da proteção integral das crianças e dos adolescentes, em respeito aos seus direitos fundamentais previstos no art. 229, bem como na plena igualdade entre os filhos, assegurado no art. $227, \$ 7^{\circ}$, ambos da Constituição. Com isso, o encaminhamento dos problemas apresentados por uma normativa que foi forjada para a família biparental deve ser buscado sempre na tábua axiológica consagrada na Constituição, em busca da máxima efetividade dos princípios constitucionais. $\mathrm{O}$ exercício responsável da parentalidade prescinde de origem, raça, sexo, cor e idade, e, por isso, deve-se garantir que os direitos ligados à reprodução e, portanto, de constituição familiar possam ser exercidos sem preconceitos e livre de discriminações.

\section{REFERÊNCIAS}

ALMEIDA, Vitor. Planejando a família in vitro: o direito ao planejamento familiar e as famílias monoparentais. Disponível em: http://www.ibdfam.org.br. Acesso em: 10 mar. 2018. 
ÁVILA, Maria Betânia de Melo. Modernidade e cidadania reprodutiva. In: ÁVILA, Maria Betânia de Melo; BERQUÓ, Elza. Direitos reprodutivos: uma questão de cidadania. Brasília: Centro Feminista de Estudos e Assessoria - CFEMEA, 1994.

BARBOZA, Heloisa Helena. A filiação em face da inseminação artificial e da fertilização "in vitro". Rio de Janeiro: Renovar, 1993.

BARBOZA, Heloisa Helena. Direito à procriação e às técnicas de reprodução assistida. In: Eduardo de Oliveira Leite et al. Grandes temas da atualidade: bioética e biodireito. Rio de Janeiro: Forense, 2004.

BARBOZA, Heloisa Helena. Novas relações de família e paternidade. In: Anais do Congresso Brasileiro de Direito de Família. Belo Horizonte: Del Rey, 1999.

BARBOZA, Heloisa Helena. Paternidade Responsável: o Cuidado como dever jurídico. In: Tânia da Silva Pereira; Guilherme de Oliveira (Org.). Cuidado e Responsabilidade. São Paulo: Atlas, 2011, p. 85-96.

BARBOZA, Heloisa Helena. Reprodução humana como direito fundamental. In: Carlos Alberto Menezes Direito; Antônio Augusto Cançado Trindade; Antônio Celso Alves Pereira. (Org.). Novas Perspectivas do Direito Internacional Contemporâneo. Rio de Janeiro: Renovar, 2008.

BODIN DE MORAES, Maria Celina. A família democrática. In: Na medida da pessoa humana: estudos de direito civil-constitucional. Rio de Janeiro: Renovar, 2010, p. 207-234.

BODIN DE MORAES, Maria Celina. O princípio da solidariedade. In: Na medida da pessoa humana: estudos de direito civil-constitucional. Rio de Janeiro: Renovar, 2010.

BRAUNER, Maria Claudia Crespo. Monoparentalidade projetada e o direito do filho à biparentalidade. In: Estudos Jurídicos, São Leopoldo, v. 31, n. 83, setembro/dezembro, 1998.

CALDERON, Ricardo Lucas. Princípio da Afetividade no Direito de Família. Rio de Janeiro: Renovar, 2013.

CASSETARI, Christiano. A multiparentalidade e parentalidade socioafetiva: efeitos jurídicos. São Paulo: Atlas, 2014.

CATALAN, Marcos. Um ensaio sobre a multiparentalidade: explorando no ontem pegadas que levarão ao amanhã. Revista da Faculdade de Direito - UFPR, Curitiba, n. 55, 2012.

COSTA, Demian Diniz da. Famílias monoparentais: reconhecimento jurídico. Rio de Janeiro: AIDE, 2002.

DINIZ, Debora. Desejo de filhos. Folha de São Paulo, São Paulo, 28 jan. 2011.

Eduardo de Oliveira Leite. Procriaçôes artificiais e o direito: aspectos médicos, religiosos, psicológicos, éticos e jurídicos. São Paulo: RT, 1995.

FACHIN, Luiz Edson. Direito de Família: elementos críticos à luz do novo código civil brasileiro. 2. ed. Rio de Janeiro: Renovar, 2003. 
FACHIN, Luiz Edson. Teoria crítica do direito civil. 2. ed., Rio de Janeiro: Renovar, 2003. GAMA, Guilherme Calmon Nogueira. A nova filiação: o biodireito e as relações parentais: o estabelecimento da parentalidade - filiação e os efeitos jurídicos da reprodução assistida heteróloga. Rio de Janeiro: Renovar, 2003.

GAMA, Guilherme Calmon Nogueira. Paternidade responsável e o cuidado: algumas reflexões. In: Andréa Ferreira, Fernando G.; Galvão, Paulo Braga (Org.). Direito contemporâneo: estudos em homenagem a Sergio de Andréa Ferreira. Rio de Janeiro: De Andréa \& Morgado, 2009.

GAMA, Guilherme Calmon Nogueira. Princípio da paternidade responsável. In: Revista de Direito Privado, n. 18, São Paulo: RT, abr./jun., 2004.

GAMA, Guilherme Calmon Nogueira. Princípio da Paternidade Responsável. In: Ricardo Lobo Torres; Eduardo Takemi Kataoka; Flávio Galdino (Org.). Dicionário de Princípios Jurídicos. Rio de Janeiro: Elsevier, 2010, p. 927-945.

GIDDENS, Anthony. A Terceira Via: reflexões sobre o impasse político atual e o futuro da social-democracia. Rio de Janeiro: Record, 2000.

Heloisa Helena Barboza. A filiação em face da inseminação artificial e da fertilização "in vitro". Rio de Janeiro: Renovar, 1993.

LEITE, Eduardo de Oliveira. Famílias monoparentais. 2. ed., São Paulo: RT, 2003.

LIPOVETSKY, Gilles. A Sociedade Pós-Moralista: o crepúsculo do dever e a ética indolor dos novos tempos democráticos. Trad. de Armando Braio Ara. Barueri: Manole, 2005.

LÔBO, Luiz Paulo Netto. Entidades familiares constitucionalizadas: para além do $n u$ merus clausus. In: PEREIRA, Rodrigo da Cunha (coord.). Familia e cidadania - Anais do III Congresso Brasileiro de Direito de Família. Belo Horizonte: IBDFAM, 2002.

MATOS, Ana Carla Hermatiuk. "Novas" entidades familiares. In: (Org.). $A$ construção dos novos direitos. Porto Alegre: Núria Fabris, 2008, p. 16-32.

MULTEDO, Renata Vilela. Liberdade e família: limites para a intervenção do Estado nas relações conjugais e parentais. Rio de Janeiro: Processo, 2017.

PIOVESAN, Flávia. Temas de direitos humanos. 2. ed., São Paulo: Max Limonad, 2003.

PIOVESAN, Flávia; PIROTTA, Wilson R. Buquetti. Direitos Reprodutivos e o Poder Judiciário no Brasil. In: OLIVEIRA, Maria Coleta; ROCHA, Maria Isabel Baltar da (Org.). Saúde reprodutiva na esfera pública e politica na América Latina. Campinas, SP: Unicamp/Nepo, 2001.

ROUDINESCO, Elizabeth. A Família em Desordem. Rio de Janeiro: Nova Fronteira, 2002.

SARMENTO, Daniel. Legalização do Aborto e Constituição. In: SARMENTO, Daniel; PIOVESAN, Flávia (Coords.). Nos Limites da Vida: Aborto, Clonagem Humana e Eutanásia sob a Perspectiva dos Direitos Humanos. Rio de Janeiro: Lumen Juris, 2007. 
SCHREIBER, Anderson. STF, Repercussão Geral 622: a Multiparentalidade e seus Efeitos. Disponível em: <http://www.cartaforense.com.br/conteudo/artigos/stf-repercussaogeral-622-a-multiparentalidade-e-seus-efeitos/16982>. Acesso em: 13 mar. 2018.

SCHREIBER, Anderson; LUSTOSA, Paulo Franco. Efeitos jurídicos da multiparentalidade. In: Pensar, Fortaleza, v. 21, n. 3, p. 847-873, set./dez. 2016.

SOUZA, Vanessa Ribeiro Corrêa Sampaio. Princípio constitucional da paternidade responsável: diretrizes para a reinterpretação do art. 1614 do Código Civil. Revista Brasileira de Direito das Famílias e Sucessóes, v. 31, 2013, p. 17-39.

SOUZA, Vanessa Ribeiro Corrêa Sampaio. Sançōes decorrentes da irresponsabilidade parental: para além da destituição do poder familiar e da responsabilidade civil. In: Civilistica.com - Revista Eletrônica de Direito Civil, a. 2, n. 2, 2013, p. 25. Disponível em: <www.civilistica.com>. Acesso 28 jun. 2017.

TEIXEIRA, Ana Carolina Brochado; RODRIGUES, Renata de Lima. $O$ direito das famílias entre a norma e a realidade. São Paulo: Atlas, 2010, p. 190-218.

VENCELAU, Rose Melo. $O$ elo perdido da filiação: entre a verdade jurídica, biológica e afetiva no estabelecimento do vínculo paterno-filial. Rio de Janeiro: Renovar, 2004.

ZURUTUZA, Cristina. Para uma convenção interamericana pelos direitos sexuais e reprodutivos. In: OLIVEIRA, Maria Coleta; ROCHA, Maria Isabel Baltar da (Org.). Saúde reprodutiva na esfera pública e politica na América Latina. Campinas, SP; Unicamp/ Nepo, 2001. 
